\title{
Governing Sustainable Development through 'Policy Coherence'? The production and circulation of knowledge in the EU and the OECD
}

\author{
Ulrike Zeigermann $^{1}$
}

\begin{abstract}
This article studies the production and circulation of approaches for sustainable development governance focusing on the 'Policy Coherence for Sustainable Development' (PCSD) concept. The concept has evolved from a side note international reports to a central target in the 2030 Agenda (SDG 17). The first part compares the understanding of Policy Coherence for Sustainable Development' in the OECD and in the EU which were essential in its emergence and dissemination. The second part relates these findings to the policy environment in which knowledge on the concept was promoted. The article argues that organisational interests contributed to the proliferation of PCSD while its added-value for sustainable development governance remains controversial.
\end{abstract}

Keywords: international organisations, policy transfer, sustainable development, coherence, OECD, EU, knowledge circulation

\section{Introduction}

In the aftermath of the 2030 Agenda for Sustainable Development which was unanimously adopted by the 193 Member States of the United on 25 September 2015, its implementation across all policy fields and levels remains a crucial challenge. Accordingly, this article studies the production and circulation of approaches for sustainable development governance focusing on the Policy Coherence for Sustainable Development' (PCSD) concept.

There is no agreement on a definition for Policy Coherence for Sustainable Development. In general, it stipulates that international cooperation policies and all other public policy areas affecting poor countries should contribute to promoting sustainable development and eradicating poverty - not only domestically but also in developing countries. This claim involves two dimensions: The first dimension refers to the absence of incoherencies across different sectoral policies (negative definition). The second dimension is the promotion of positive synergies through making Policy Coherence for Sustainable Development itself an overarching policy goal (positive definition) (cf. Ashoff 2005). As such, in its first dimension, the concept entails the aspect of improving the development cooperation system through better coordination across sectoral departments and policy instruments in order to support rather than undermine oneanother through incoherencies. The second dimension encompasses promoting sustainable development as an overarching policy goal which should be mainstreamed

${ }^{1}$ Department for Society, Politics and Transformation, Otto von Guericke University, Magdeburg, Germany. 
across all national governments, international organisations, levels and sectors of public decision-making.

Since the early 1990s, the concept has spread internationally (cf. Forster and Stokke 1999). The following figure illustrates that PCD has evolved from a side-note in the Treaty of the European Union and reports of the Development Assistance Committee (DAC) of the Organization for Economic Co-operation and Development (OECD) towards a global target of the Sustainable Development Goals (SDG17).

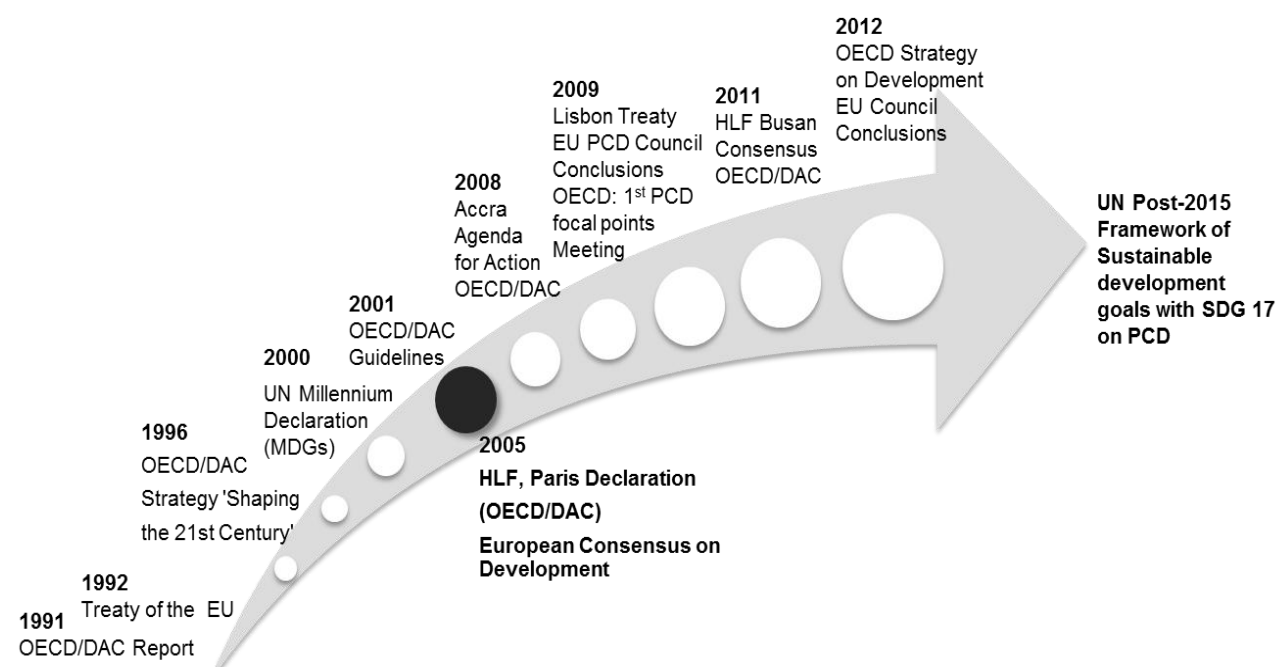

Figure 1:The proliferation of PCSD in international agreements

This article discusses the reasons for the proliferation of the of the PCSD concept in the OECD and the EU and its translation for sustainable development governance. The analysis is based on 49 semi-structured interviews with EU and OECD officials, participant observation undertaken from October 2013 to March 2014 in the OECD Secretary General's Office and EU meetings, and qualitative analysis of official documents. The first part compares the evolving understanding of PCSD. The second part discusses the role of both international organizations in producing hegemonic knowledge and international norms.

The article argues that organizational interests related to the structure and mandate of the EU and the OECD have contributed to the increasing circulation of the PCSD concept. At the same time, its added-value for governing sustainable development remains controversial - both at the theoretical and at the practical level.

\section{Policy innovation for sustainable development in international organizations}

Ernst Haas (1990) has argued that international organizations are important "innovators" in international relations. In this chapter, I analyze the capacity of the EU and the OECD to produce innovative ideas for sustainable development governance, focusing on the idea of Policy Coherence for Sustainable Development. According to 
Haas and Haas (1995) I consider international organizations as learning institutions with important capacities and resources which are responsive to emerging political issues, policy challenges, new methods and international developments. I assume that they are able to define problems and subsequently produce consensual knowledge through circulating and discussing new ideas, approaches and concepts. Following E.M. Rogers (2003) thoughts on diffusion of innovations, I am interested in whether PCSD is perceived as a new approach as compared to previous concepts and practices and not whether or not the idea is "objectively" new (Rogers 2003, 12).

\subsection{The evolving Policy Coherence for Sustainable Development concept in the EU}

In 1992, the Maastricht Treaty introduced the policy coherence concept in the treaty establishing the European Union (in Title XVII on development cooperation) ${ }^{1}$. It presented the three C's - coordination, complementarity and coherence - emphasizing that EU development policy should complement member states' development policies. This was perceived as an important new step towards greater European Integration and as a requirement against the background of a new international environment. The end of the cold war changed the role and focus of international cooperation which was until then very much determined by political interests of the two blocks. In addition, the Maastricht treaty stated that other EU policies should at least not contradict or undermine the intended results or aims of development policy. This aspect was considered a necessary organizational adaptation with regard to increasing institutional complexity of the newly created European Union.

In the following years between 1992 and 2005, the notion of policy coherence for development was increasingly used in statements and policy programs on very different topics - mostly related to agricultural export subsidies of the EU which were found to put downward pressure on the level of world market prices producing unfair competition in many developing countries. At the same time, was there was a very controversial debate on how to understand the new 'coherence' requirement, i.e. its expected purpose; its operationalization for policy formulation, implementation and evaluation; and its focus. There was also no agreement on the link between 'policy coherence' and the abstract notion of 'development'. As a result, there was no production of detailed definitions or policy analyses as the emergence of new concepts would otherwise suggest (Nay 2014: 2015).

In 2005, the European Commission, the Parliament and the Council jointly adopted the European Consensus on Development containing a commitment to PCD and a list of 12 relevant policy areas: Climate Change, Security, Environment, Employment, Trade, Social Policy, Agriculture, Fisheries, Migration, Research and Innovation, Transport and Energy and Information. The focus of the EU was to align different policies which were considered to have an impact on developing partner countries. The stated purpose of greater coherence across those policy areas was justified with avoiding duplication and thereby increasing the efficiency of processes in the EU and the effectiveness of EU

1 Articles 178 and 180 of the Treaty of the European Community (TEC) became the new article 208 of the Treaty on the Functioning of the European Union (TFEU) in 2009. 
policies.

As part of the 2005 EU Consensus on Development, the EU also committed to an evaluation process which assesses EU policies in particular but which has been linked to evaluations of member states policies over the years. Since 2007, the European Commission has produced a Policy Coherence for Development report every two years. These reports focus, however, on coordination. Between 2007 and 2015 analyses have mainly dealt with evaluating bureaucratic arrangements, technical and managerial processes within the EU. Therefore, authors have criticized that the EU and its member states are only paying lips-service to enhancing PCD without making real efforts for systematically analyzing the effects of EU policies in developing countries (Picciotto 2005; Carbone 2008a,b; Keijzer and Oppewal 2012; Carbone and Keijzer 2016).

While coordination is considered to be an important element of PCD, policy coherence is not automatically the result of successful coordination but requires political decisions across all policies and member states despite increasing heterogeneity that consider the development of poor countries (cf. May, Sapotichne, and Workman 2006; Barry, King, and Matthews 2010; Carbone and Keijzer 2016). As such, the design of European assessment tools demonstrates the objective to enhance EU capacities of developing policy-making standards and increasing technical knowledge on coordination instruments and international cooperation programs justified by efficiency and effectiveness. This approach was also supported by member states which is highlighted by their willingness to contribute to those reports with country experiences and the appointment of a Standing Rapporteur for Policy Coherence for Development by the Development Committee of the European Parliament in 2010.

The High Representative and the European Commission presented a Joint Communication on the EU Comprehensive Approach in December 2013 (JOIN(2013) 30 final). It lays out a strategy on working better together and enhancing the coherence, effectiveness and impact of the EU's policy and action, in particular in relation to conflict prevention and crisis resolution, emphasizing the importance of shared analysis and the use of collective resources and instruments. As previous initiatives, however, this approach remains focused on EU-internal mechanisms related to coordination, joint analysis, joint programming and joint evaluation. It builds on the EU's cognitive and technical knowledge on these issues.

Only recently, in the context of the preparation of the 2030 Agenda including the Sustainable Development Goals (SDGs) after the Rio+20 Summit in 2012 the EU began to frame the concept as 'Policy Coherence for Sustainable Development'. This change in the discourse reflects a shifting focus from the absence of incoherencies towards a positive definition of PCSD as an overarching policy goal which is linked to global sustainability commitments of the EU.

\subsection{Policy Coherence for Sustainable Development in the OECD}

According to the OECD, the idea of policy coherence for development emerged in the Development Assistance Committee (DAC) of the OECD in 1991 in the context of international debates on aid effectiveness (OECD/DAC 2003: 2). The first explicit reference appeared in 1996 in the Strategy "Shaping the 21st Century" (OECD 1996) and the first definition was published in in the DAC Guidelines on Poverty Reduction in 
2001 only, i.e. ten years after it was first presented within the DAC, stating: "Policy coherence is needed, therefore, to ensure that globalization works for all. Coherent policies can overcome the asymmetries that creep into the globalization process, often because of policy incoherence in both developed and developing countries. [...] it involves the systematic promotion of mutually reinforcing policy actions across government departments and agencies creating synergies towards achieving the defined objective" (OECD/DAC 2001: 103-104)

Policy Coherence for Development (PCD) was systematically integrated into the DAC Peer Reviews which assess development cooperation efforts of its 29 members. Within those reports, PCD has taken an ever prominent position from a single paragraph towards an own section mainly assessing institutional arrangements. In those reports, policy coherence for development has been linked to preexisting concepts of aid effectiveness and do no harm. These reports argue in favor of synergies across different policy fields in order to avoid incoherencies which are considered problematic because of the costs linked to inefficient, ineffective and in the worst case contradictory policy-making. The OECD recommended accordingly, "governments need to ensure that their policies on issues which go beyond aid and development assistance are supportive of, or at least do not undermine, their development-focused policies. This is the policy coherence for development (PCD) agenda" (OECD 2009: 15).

Through the OECD/DAC Peer Reviews, monthly meetings and annual high-level intergovernmental high-level meetings of DAC member states which are prepared by the Development Assistance Committee with support of the Development Co-operation Directorate (DCD) and the Secretariat, the DAC has contributed to sharing knowledge on policy coherence for development and to shaping the concept. This has also led to the Paris Declaration (2005), Accra Agenda for Action (2008), the High Level Forum in Busan Consensus (2011) and the OECD Strategy on Development (2012), which are the main international agreements constituting references for the OECD on PCD.

With increasing debates and publications along the 2009 established OECD/PCD Focal Points Meetings, the OECD has started to develop PCD indicators and to discuss PCD approaches. These efforts - more than ten years after starting to engage with PCD in the DAC - focused on institutional approaches to make the OECD and governments in member states more efficient. As such, for a long time, the OECD framework for PCD assessment concentrated on general provisions regarding building blocks for policy coherence (OECD 2009). Those building blocks for PCD were represented in a policy cycle for development. This PCD cycle included the blocks: policy formulation, implementation and evaluation.

As the analysis of the agendas, summary records and available documentation on the content shows, the first two OECD/PCD Focal Points meetings (2009 and 2010) focused on situating the PCD debate in the broader context of development cooperation, aid challenges for donor countries, and institutional practices within the OECD and in participating member states. With a greater focus on development effectiveness (after Busan 2011) and joint efforts of the EU and the OECD to incorporate the PCD concept in the global framework for a post-2015 Sustainable Development Agenda greater attention was attributed to "integrating the multiple dimensions of development at all stages of policy making" (OECD 2013: 2) and promoting mutual positive synergies for sustainable development in all countries. 
The 2012 Strategy on Development was agreed in the OECD's Member's Council and has set the main framework for promoting PCD across the OECD, its member states and beyond. It reflects an important shift compared to previous policy recommendations and approaches from the OECD which focused on DAC member countries' official development assistance (ODA) policies towards a new issue-based approach focusing on the global effects of policy decisions, starting with analyses on food security (2012), illicit financial flows 2014) and green growth (2015).

The OECD has actively engaged in the production of new knowledge on PCD through publications, international conferences and in cooperation with the Knowledge Sharing Alliance which was established as the second pillar of the 2012 Strategy on Development. This has not only led to the changing name from "Policy Coherence for Development" to "Policy Coherence for Sustainable Development". The organization also developed monitoring frameworks for tracking progress for PCSD at the national level (OECD 2016, Morales \& Lindberg 2017) and has set up a platform for a global PCSD partnership for implementing SDG 17.

\subsection{Towards a common understanding of 'Policy Coherence for Sustainable Development'}

Comparing the process of defining Policy Coherence for Sustainable Development in the EU and the OECD, analysis shows that both international organizations have used the concept very early with reference to globalization processes, international and organizational complexity, and poverty reduction in developing countries. Common characteristics of the emerging concept are:

PCSD is framed as a results-based framework, assuming that qualitatively better policy coherence contributes to better outcomes and impacts for sustainable development not only domestically but also in partner countries.

Yet, the early concept focuses on challenges of ODA donor countries. Despite the integration of new perspectives and increasing commitments over the years, studies on policy effects and living conditions in developing partner countries or voices from the Global South are not systematically considered for developing and formulating PCSD approaches.

It specifically targets institutional and policy challenges of development policies of EU or OECD/DAC member states. The idea concentrates on aid effectiveness and coordination mechanisms across different agencies, departments and policy objectives with a view to increasing efficiency and economic growth.

The concept concentrates primarily on the institutional setting of governmental departments and agencies. It is barely linked to other actors of international cooperation, such as civil society or private businesses.

Despite the integration of new perspectives and the active engagement of the EU and the OECD to promote Policy Coherence for Sustainable Development as an innovative approach in policy statements, reports, publications, strategy papers and monitoring frameworks, and the incorporation of the concept into the SDG framework, its practical use for sustainable development governance remains controversially discussed. Researchers have referred to the PCSD concept as a "mission impossible" (Carbone 2008b); a "buzzword" (Obrovsky and Schlögl 2011: 9); an "euphemism for the recognition of failed 
coordination between development and other public policies" (Thema 2011:174) or a "hobgoblin" (Barder 2013).

These references demonstrate the discrepancy between what is promoted as an innovative approach through policy debate and instruments by the EU and the OECD vs. how PCSD is discussed by other experts who do not consider the concept to be an innovative approach for sustainable development governance.

\section{The translation of Policy Coherence for Sustainable Development}

The framing of PCSD as illustrated in the first part of the paper appears as a political act. In order to better understand the idea for sustainable development governance promoted by the OECD and the EU, the second part studies the intellectual, political and institutional context in which the PCSD concept has evolved.

\subsection{The intellectual environment in which PCSD has emerged}

PCD is anchored and has evolved simultaneously to international debates on socalled comprehensive concepts. In particular, it can be linked to theories of good governance with a special focus on developing countries (cf. Kröger 2008; Joshi 2011; UNDP 2012; Sinclair 2012; Fukuyama 2013; Halleröd et al. 2013; Weiss 2013), sustainable development (cf. Moore 2015; Moran et al. 2008; Srivastava 2011; Scott and Lucci 2015) and buman rights based approaches to development (cf. Chinkin 2001; Pogge 2002Alston 2005; Alston and Robinson 2005; OECD and Worldbank 2006). Drawing on those ideas, the emergence of the PCD concept meant a shift from focusing on policies of developing countries that were supposed to change through international development cooperation towards a new paradigm focusing on domestic policies of developed countries. As such, policy coherence for development has highlighted the idea that developed countries have to change their policies in order to avoid negative external effects for developing countries. Many researchers have emphasized the growing importance of interlinked processes and policies related to globalisation. They have demonstrated that not only external policies but also domestic political decisions may have an impact on the political and economic situation in other countries (cf. Strang 1991; Simmons and Elkins 2004, 2005). As such, the PCSD concept has emerged and evolved around the ever more prominent idea that governments can through both their domestic and international policies help poor and conflict affected partner countries in their economic and social development and, at the same time, ensure that their own development is not negatively affected, but reinforced through coherent activities and instruments that reflect both the impact of policies domestically and in the Global South. Concepts that are linked to that idea include in particular ideas related to multilevel and multi-actor governance and approaches to decisionmaking processes such as the institutional collective action framework (Feiock 2013) or the Social-Ecological Systems Framework (cf. Ostrom and McGinnis 2014). These theories have also provided valuable insight to the policy processes linked to PCSD.

Policy coherence is also similar to the concept of mainstreaming. The exact definition of mainstreaming remains contested among researchers. Generally, it refers to working towards achieving 'borizontal objectives' that are also an essential dimension of policy coherence. Policy coherence for sustainable development and sustainable development 
mainstreaming are both about promoting development concerns across all levels of political decision-making and policy areas. According to Keijzer and Oppewal (2012), however, the "crucial difference between the two concepts is that mainstreaming does not involve the managing of political trade-offs, while that is a crucial element in promoting coherence" (Keijzer and Oppewal 2012, 4). The OECD and the EU have built on ideas of mainstreaming and are linking both terms as, for instance, in the context of developing a mainstreaming development matrix for measuring PCD performance within the OECD for the 2014 progress report on the 2012 Strategy on Development (OECD 2014a).

Approaches of policy integration, notably environmental policy integration (cf. Underdahl 1980; Persson 2004; Mickwitz et al. 2009), which consider policy output as a dependent variable, emphasize the idea of sustainable development and environmental sustainability in particular through integrated policy making. This results-based approach is very similar to the idea of policy coherence for development. The OECD and the EU have both emphasized the results-based approach drawing a link between incoherencies, inefficient policy making and ineffectiveness of development cooperation in the 2005 Paris Declaration and in the European Development Consensus. Notably in the context of the SDG debates in which both international organisations were involved and promoted the PCD concept, the issue of expected results were tabled. Accordingly, PCD is considered to be a concept not just to change bureaucracies but also to ultimately transform daily habits and people's lifes not only domestically but also in developing partner countries. Consequently, the idea of "policy coherence" and "policy coherence for sustainable development" in particular builds on other policy frameworks adding new aspects for sustainable development governance. Its originality and use remain, however, contested due to its vague conceptual framework and difficult implementation (cf. Eyben 2007, Carbone 2013, Wunderlich 2013, Siitonen 2015).

\subsection{The policy environment in which the idea has circulated through the EU and the OECD}

The European Union and its member states are the leading donors of official development assistance in the world reaching $€ 75.5$ billion in 2016. This constitutes an $11 \%$ increase compared to 2015 level (representing approx. 0.51\% of EU gross national income). As such, the Policy Coherence for Development agenda may contribute to the EU's positive international reputation for development cooperation and is seen as an effort for more efficient and more effective decision-making and forward-looking approach to new global challenges.

As a political organization being directly linked to EU citizens, the following aspects constitute both an organizational incentive and a factor hampering the framing of the PCSD concept: main beneficiaries of policy coherence for sustainable development are located in developing countries far away; and potential positive development impacts may be attained much later than the political decision. On the one hand, this blurs results chains to justify political action to the electorate and has contributed to scepticism towards the concept. On the other hand, being the largest international provider of ODA, the EU has a strong incentive to show results of its work and spending. Since EU development policy alone cannot contribute to those results, the promotion of policy coherence for development promises more positive outcomes which increase the 
influence of the EU as an actor in international development cooperation. In addition, as a political actor the EU is interested in a stable international environment and strong economic partnerships. The expected effects attributed to PCSD contribute to that aim. The OECD has been described as an "idea inventor," "idea arena", "idea agent", "idea merchant" and "idea authority" (Marcussen 2002) and Sylvia Ostry of the OECD commented, "a great advantage of the OECD is that it has no power but great influence" (1992). The production and sharing of theoretical and empirical knowledge on Policy Coherence for Development is mandated by member states but the influence and authority of the DAC, DCD, the Secretariat of the OECD which are involved in setting the agendas for OECD Members' Meetings and which can use their knowledge strategically should not be underestimated. The cognitive and technical influence (cf. Nay 2012:58) through which the OECD can define soft regulations is most important to understand the policy environment in which the PCSD concept has emerged, i.e. the capacity of the organization to develop technical frameworks, statistical indicators, evaluation mechanisms and informal standards, and to circulate information and convince countries to adopt recommendations.

Over more than 20 years after 1991 approaches and frameworks for policy coherence for development focused on general institutional settings and regulatory policies. Those were used for key areas of activity of the OECD, i.e. promoting economic growth and wellbeing through the work of its directorates on trade, agriculture and fisheries (OECD 2005,2006,2013a, Brooks 2014, migration (OECD 2005b, 2007, 2009a) and the environment (OECD 2003, 2008d).

Following the mandate of the 2012 Strategy on Development three thematic priorities were set: food security, illicit financial flows and green growth (OECD 2012). Those thematic priorities reflect the international policy debate not only in the OECD but also in other international forums, such as in the context of the United Nations or the G20. The draft of that strategy was prepared by the DAC and the Secretariat through preparatory meetings reflecting international trends, OECD analyses and expertise. For the drafting of pilot reports (OECD 2013, 2014, 2015) on the three thematic priorities, member states were required to provide country data and received policy recommendation. Thus, although the OECD has no legal instruments, it can influence the course of its own work and the priorities and practices of member states through indirect mechanisms of agenda-setting, data collection, information-sharing and policy recommendation as its soft power.

\subsection{The organizational setting for the production and promotion of PCSD}

Within the OECD, PCD was initially a project of the OECD Development Cooperation Directorate but it was moved at Secretariat level with the increasing importance attributed to the issue. With the move to the OECD Secretariat PCD has been linked to the work of a Deputy Secretary-General. There have also been more statements on PCD from the Deputy Secretary-General and the OECD SecretaryGeneral in opening remarks of OECD conferences and meetings with heads of governments, in introductory statements of OECD publications on thematic issues (such as migration, agriculture, illicit financial flows, green growth or responsible business conduct), and in Council Meetings. The move to the Secretariat gives the PCD unit also 
greater power with regard to other directorates. PCD has thus become an instrument of organizational coordination and priority-setting.

Since 2012 PCD was framed as one of the two central pillars of the OECD Strategy on Development together with knowledge sharing. The Knowledge Sharing Alliance Unit and the PCD Unit have been working closely together since then - not only through physical proximity having both their offices in the same floor in the 'Chateau', the secretariat and heart of the OECD, but also through common projects and approaches. Knowledge-sharing has become a tool for spreading the PCD concept within the different directorates and departments of the OECD and across member states, professionalizing and enhancing formalized mechanisms for organizational learning, feedback and spreading information.

In addition, different pre-existing and parallel work streams of the OECD are very similar to the Policy Coherence for Development agenda. First, the Governance and Peace department of the Development Cooperation Directorate has worked on do no harm and whole-of government approaches for institution-building and conflict prevention in fragile and conflict-affected states. Their work focuses on questions related to governance, coordination and cooperation to align different policies and stakeholders in conflict-affected regions. The idea of PCD, which was initially a project of the Development Cooperation Directorate, has built on those ideas without, however, systematically pursuing both issues together. OECD/PCD meetings are not systematically linked to the work of the International Network on Conflict and Fragility $\left(\mathrm{INCAF}^{2}\right)$. Yet, the network discusses issues that are very similar to the PCD debate (Lindberg 2012, OECD 2012: 1, Whaites 2015: 9).

In March 2014 the PCD focal points meeting in Paris has emphasized the role of socalled centre of government actors for PCD. By centre of government actors the OECD understands those actors who are working at the heads of governments' offices and being senior national officials because they are assumed to have greater capacity for coordination than other public officials and are able to determine political priorities, i.e. making sustainable development a central focus of government action and policy formulation. The Network of Senior Officials from Centres of Government (CoG) is no new platform in the OECD. CoG meetings have been established as early as in the 1980s, and were consolidated into an annual event since 1995. The meetings are organised as a forum for informal discussion and are one of the OECD's highest-level policy networks. The meeting summaries (2010-2015) and agendas (2006-2015) of those meetings emphasize that the purpose of those meetings has been the discussion of broad governance and decision-making issues, the exchange of experiences and getting to know each-other in order to work effectively together. The meetings have dealt with government capacity of crisis management (anticipating, managing and evaluating vulnerabilities); challenges related to the financial and economic crisis in Europe and in the world; and long-term strategy-development and implementation vs. responding to electorate expectations. The 2015 meeting has particularly addressed the issue of whole-

\footnotetext{
${ }^{2}$ INCAF is a subsidiary body of the OECD Development Assistance Committee (DAC). It was created in 2008 merging the former DAC Fragile States Group (FSG) and the DAC network on Conflict, Peace and Development Cooperation (CPDC) (OECD 2016a).
} 
of government approaches and knowledge promote sustainable development within the framework of the SDGs. Although those meetings have only recently been linked to PCD issues, the participants in those meetings - in the case of France a Director under the Prime Minister, in the case of the UK the Cabinet Secretary and Head of Civil Service, in the case of Germany the Deputy Director-General of the Federal Chancellery (Kanzleramt) - can be considered as important intermediaries transferring knowledge to the national level.

Some experts have criticized the existence of two similar approaches which are not linked and the lack of incentives and authority for coordinated PCD action. However, through connecting different structures and networks to the PCD framework, PCD has not only gained importance within the OECD but it has also helped the organisation to control and spread information and knowledge to member states and other international organizations across different agencies. Combining knowledge and technical instruments from different OECD agencies, framing those approaches under a new PCD label and promoting them to member states in a combined effort of different OECD agencies can further increase the influence of the OECD whose authority derives from its power to control and share information.

Those dynamics within the OECD indicate organisational preferences and motivations related to the framing and dissemination of PCD in order to increase the capacity to develop technical instruments, set rules and standards, gather and share information, and ultimately influence stakeholders. It shows that there is increasing support for PCD within the OECD despite remaining institutional duplications and rivalries, notably by moving the PCD unit to the Secretariat and linking it to the CoG Network.

In the EU, member states have agreed to transfer some of their power to the EU. EU institutions can therefore create binding standards in supranational decision-making processes for specific policy areas, including on the budget. Consequently, the EU has not only promoted policy coherence for development through communicative processes and reports as laid out in the constituting documents but also through legal instruments. The Lisbon Treaty (2009) established the legal basis for compliance with PCD standards that go beyond simple coordination issues, stating: "The Union shall take account of the objectives of development cooperation in the policies that it implements which are likely to affect developing countries" (Article 208 (1) TFEU). Art. 208 (1) TFEU requires the EU to take development issues into account and then decide without, however, having to prioritize development objectives. In other words, the EU can maintain policies that have negative side-effects for developing partner countries - so long as it considers the issue, notably through impact assessments which were introduced in 2009. Those assessments are published as annexes to the legal provisions and examine the potential impact on developing countries (Dunlop and Radaelli 2016) ${ }^{3}$.

Paul Hoebink (2004) has illustrated that different actors have been pushing policy coherence for development within the EU institutions (Hoebink 2004b). Different Directorate Generals have diverse and sometimes clashing geographical and thematic

\footnotetext{
${ }^{3}$ Although these impact assessments show the willingness of the EU to PCD, their quality and underlying paradigms (European Commission 2009b) determining these examinations can be critically discussed (Hayes und Westrup 2012; Rijksoverheid 2013; Dunlop und Radaelli 2016).
} 
priorities regarding policy objectives and procedures which are determining the process of balancing political interests in the decision-making processes in the EU. For instance, those differences were revealed at the occasion of economic partnerships (Carbone 2007; Young und Peterson 2013). So, unlike the OECD where the overall objective of promoting sustainable development through analysis of data and the development of concepts is not contested, in the EU rivalries are of a more fundamental nature.

Non-governmental stakeholders are also influencing the decision-making processes of the EU from outside through political pressure on politicians regarding certain issues (namely in the fields of agricultural and trade policies) with a view to framing policy problems and - more importantly - policy solutions which reflect the different interests. The work of CONCORD which publishes alternative EU PCD reports (cf. Concord 2009, 2011, 2013, 2015a, 2015b) can be considered as particularly important for framing PCD but other actors representing notably business interests, agricultural, national security or anti-migration interests are also determining the policy environment in which the EU has developed and promoted the PCD concept.

It has been argued that policy coherence of external action may finally reproduce and reinforce traditional habits; thereby subordinating development policy to other polices (Carbone 2013; Keukeleire and Raube 2013; Carbone and Keijzer 2016). Those rivalries emphasize that policy coherence for sustainable development is a very political issue in the EU. The emergence and enhancement of the concept depends on political will of the multiple actors involved. Commitments and PCSD strategies reflect a compromise not only between different Directorate Generals, member states and other stakeholders but also negotiations with developing partner countries.

Finally, there are specific interests between the EU and the OECD determining the framing and promotion of policy coherence for development. Maurizio Carbone (2012) finds institutional rivalry between the DAC and the European Commission in framing the concept (Carbone 2012, 170). Both have put efforts into broadening and enhancing the concept, suggesting institutional requirements for improving PCD (OECD 2009a). The interests beyond those approaches remain, however, controversially discussed (Carbone 2013a,b; Thede 2013; Young and Peterson 2013; Carbone and Keijzer 2016). On the one hand, both the OECD and the EU have an interest in lifting developing partner countries out of poverty and conflict to establish strong and stable partnerships, and create concepts, mechanisms and processes that promote that goal (i.e. PCSD). On the other hand, there is the question if the policy coherence for sustainable development framework is reinforcing traditional power relations, i.e. North-South dependencies, hierarchies fostering the power of certain actors, policy sectors, departments and organizations at the expense of others. As such, the approach may promote the visibility of the EU and the OECD in international affairs and development cooperation through the setting of new standards but not necessarily benefit sustainable development and poor countries in particular. It has even been argued that integrated frameworks such as PCSD are used as a rhetorical tool to shift and blur responsibilities of agencies (Carbone 2012; Keukeleire and Raube 2013; Young and Peterson 2013). Although no final responses are possible in that regard, those critical reflections are important to understand the international policy and structural environment in which the concept has emerged. 


\section{Conclusion}

This article underlines the need to take a closer look at power relations and hierarchies linked to the emergence and circulation of the Policy Coherence for Sustainable Development. Among the main promoters of the concept between 1990 and 2015 - the OECD and the EU - organizational interests are reflected in, rivalries across different departments and institutional hierarchies and competition with non-state actors and regarding the framing of the concept, integration of different networks, approaches and stakeholders to the policy coherence for sustainable development debate in order to broadly circulate the idea and create consensual knowledge based on own ideas, common paradigms of multilateralism, interconnected global processes and international competition which require PCSD, and a focus on the global North and member states in particular.

Policy Coherence for Sustainable Development appears as a political discourse while its added-value for governing sustainable development remains controversial due to focus on framing the concept and formulating policy strategies and recommendations instead of actually changing policy objectives or instruments (cf. Carbone 2016). The EU and the OECD have promoted the PCSD concept as a new approach and innovative framework for better policy making. Yet, even among experts from within both international organization and from scholars the innovative nature and scope of the concept remains very controversial.

\section{References}

Ashoff, Guido.2005. Enhancing policy coherence for development: justification, recognition and approaches to achievement. Bonn: Deutsches Institut für Entwicklungspolitik.

Alston, Philip. 2005. „Ships passing in the night: the current state of the human rights and development debate seen through the lens of the Millennium Development Goals" Human Rights Quaterly, Vol 27, No. 3: 755-829.

Alston, Philip, and Mary Robinson. 2005. Human Rights and DevelopmentTowards Mutual Reinforcement. Oxford University Press.

Barder, Owen. 2013. „Policy Coherence Is a Hobgoblin“. Center For Global Development. September 26. http://www.cgdev.org/blog/policy-coherence-hobgoblin.

Barry, Frank, Michael King, and Alan Matthews. 2010. „Policy Coherence for Development: Five Challenges". Irish Studies in International Affairs 21 (Januar): 207-23.

Carbone, Maurizio. 2007. The European Union and International Development: The Politics of Foreign Aid. Routledge.

2008a. „Better Aid, Less Ownership: Multi-Annual Programming and the EU's Development Strategies in Africa“. Journal of International Development 20 (2): 218-29.

2008b. „Mission Impossible: the European Union and Policy Coherence for Development“. Journal of European Integration 30 (3): 323-42.

2012. „Beyond Aid: Policy Coherence and Europes Development Policy“. In International Development Policy: Aid, Emerging Economies and Global Policies, edited by Gilles Carbonnier, 161-73. New York: Palgrave Macmillan.

—. 2013a. „International development and the European Union's external policies: changing contexts, problematic nexuses, contested partnerships“. Cambridge Review of International Affairs 26 (3): 483-96.

—. 2013b. Policy Coherence and EU Development Policy. Routledge. 
. 2016. „The European Union and Policy Coherence for Development: high on mechanisms, low on achievements“. Expert Briefing. Brussels: European Commission.

Carbone, Maurizio, and Niels Keijzer. 2016. „The European Union and Policy Coherence for Development: Reforms, Results, Resistance“ European Journal of Development Research (Vol. 28. Issue 1): 30 43.

Concord. 2009. „Spotlight on Policy Coherence“. Spotlight on Policy Coherence for Development. Brussels: Concord.

. 2011. „OECD: CONCORD (2011), Spotlight on EU Policy Coherence for Development.pdf“. Brussels: CONCORD.

. 2013. „The real life impact of EU policies on the poor“. Spotlight on EU Policy Coherence for Development. Brussels.

. 2015a. „Operationalizing Policy Coherence for Development“. Spotlight on EU Policy Coherence for Development. Brussels: Concord.

. 2015b. „The European Commission’s ,Better Regulation Package‘. Will it serve poverty eradication and human rights?" Spotlight on Policy Coherence for Development. Brussels: Concord.

Eyben, Rosalind. 2007. „Harmonisation: How Is the Orchestra Conducted?“ Development in Practice 17 (4/5): 640-46.

Brooks, Jonathan. 2014. „Policy Coherence and Food Security: The Effects of OECD Countries' Agricultural Policies“. Food Policy 44:88-94. https://doi.org/10.1016/j.foodpol.2013.10.006.

Dunlop, Claire A., and Claudio M. Radaelli. 2016. Handbook of Regulatory Impact Assessment. Edward Elgar Publishing.

Elkins, Zachary, and Beth Simmons. 2005. „On Waves, Clusters, and Diffusion: A Conceptual Framework“ The Annals of the American Academy of Political and Social Science:33-51.

European Commission. 2009. Impact Assessment Guidelines. SEC (2009) 92. Brussels. http://ec.europa.eu/smart-regulation/impact/commission_guidelines/docs/iag_2009_en.pdf.

Faist, T., M. Fauser, and P. Kivisto. 2011. The Migration-Development Nexus: A Transnational Perspective. New York: Springer.

Feiock, Richard C. 2013. „The Institutional Collective Action Framework“. Policy Studies Journal 41 (3):397425. https://doi.org/10.1111/psj.12023.

Fukuda-Parr, Sakiko. 2003. „THE HUMAN DEVELOPMENT PARADIGM: OPERATIONALIZING SEN'S IDEAS ON CAPABILITIES“. Feminist Economics 9 (2-3):301-17. https://doi.org/10.1080/1354570022000077980.

Fukuyama, Francis. 2013. „What Is Governance?“ Governance 26 (3):347-68. https://doi.org/10.1111/gove.12035.

Haas, Ernst B. 1990. When Knowledge is Power: Three Models of Change in International Organizations. Bd. 9. Berkely: University of California Press. http://dx.doi.org/10.1080/08109029108631922.

Haas, Peter M., and Ernst B. Haas. 1995. „Learning to Learn: Improving International Governance“. Global Governance 1 (3):255-84.

Halleröd, Björn, Bo Rothstein, Adel Daoud, and Shailen Nandy. 2013. „Bad Governance and Poor Children: A Comparative Analysis of Government Efficiency and Severe Child Deprivation in 68 Low- and Middle-income Countries“. World Development 48 (August):19-31. https://doi.org/10.1016/j.worlddev.2013.03.007.

Hayes, Niall, and Chris Westrup. 2012. „Power/Knowledge and Impact Assessment: Creating New Spaces for Expertise in International Development.(Report)“. New Technology, Work and Employment 27 (1):9.

Hoebenik, Paul. 2004a. „Evaluating Maastricht's Triple C: An introduction to the development paragraphs of the Treaty on the European Union and suggestions for its evaluation". In The Treaty of Maastricht and Europe s Development Co-operation, 1-24. Brussels: Aksant Academic Publishers,. http://docplayer.net/6545863-The-treaty-of-maastricht-and-europe-s-development-cooperation.html.

2004b. „Evaluating Maastricht's Triple C: The 'C' of Coherence“. In The Treaty of Maastricht and Europe s Development Co-operation, 183-218. Brussels: Aksant Academic Publishers,. http:/ / docplayer.net/ 6545863-The-treaty-of-maastricht-and-europe-s-development-cooperation.html. 
Joshi, Devin. 2011. „Good Governance, State Capacity, and the Millennium Development Goals“. Perspectives on Global Development and Technology 10 (2):339-60. https://doi.org/10.1163/156914911X582468.

Keijzer, Niels, and Jorrit Oppewal. 2012. Learn to walk before you run? A review of methodological approaches for evaluating coherence in the field of international cooperation. Discussion Paper 132. ECDPM. www.ecdpm.org/dp132.

Keukeleire, Stephan, and Kolja Raube. 2013. „The security-development nexus and securitization in the EU's policies towards developing countries“. Cambridge Review of International Affairs 26 (3):556-72. https://doi.org/10.1080/09557571.2013.822851.

Lindberg, Carina. 2012. „Conflict and fragility. Policy Coherence Challenges in the ,conflict and fragility issue area". Backgro and Paper. Paris: OECD. https://community.oecd.org/docs/DOC-49220.

May, Peter J., Joshua Sapotichne, and Samuel Workman. 2006. „Policy Coherence and Policy Domains“. Policy Studies Journal 34 (3):381-403. https://doi.org/10.1111/j.1541-0072.2006.00178.x.

Mickwitz, Per, Nils Ferrand, Christian Kuhlicke, Matti Melanen, Hugo Reinert, Francisco Aix, Silke Beck, u. a. 2009. Climate Policy Integration, Coherence and Governance. PEER Report No 2. Helsinki: Partnership for European Environmental Research. http://www.peer.eu/fileadmin/user_upload/publications/PEER_Report2.pdf.

Moore, Henrietta L. 2015. „Global Prosperity and Sustainable Development Goals“. Journal of International Development 27 (6):801-15. https://doi.org/10.1002/jid.3114.

Musekamp, Simon. 2008. „Kohärenz zwischen deutscher Entwicklungs- und Migrationspolitik“. In Migration und Entwicklung. Dossier, 48-53. Berlin. http://www.migrationboell.de/pics/Dossier_Migration_und_Entwicklung.pdf.

Nay, Olivier. 2012. „How do policy ideas spread among international administrations? Policy entrepreneurs and bureaucratic influence in the UN response to AIDS“. Journal of Public Policy 32 (01):53-76. https://doi.org/10.1017/S0143814X11000183.

2014. „International Organisations and the Production of Hegemonic Knowledge: how the World Bank and the oecd helped invent the Fragile State Concept". Third World Quarterly 35 (2):210-31. https://doi.org/10.1080/01436597.2014.878128.

Obrovsky, Michael, and Lukas Schlögl. 2011. Politikkobärenz durch Kobärenzpolitik!: Bedingungen für Policy Coherence for Development in Österreich. 1. Aufl. Südwind Wien.

OECD, Hrsg. 2003. The Environmental Performance of Public Procurement. Paris: OECD Publications.

2005a. Fostering Development in a Global Economy. Paris: OECD Publishing. http://www.oecdilibrary.org/content/book/9789264010154-en.

, Hrsg. 2005b. Agriculture and Development The Case for Policy Coherence. Paris: OECD Publications.

., Hrsg. 2006. Fishing for Coherence Fisheries and Development Policies. Paris: OECD Publications.

. , Hrsg. 2007. Policy Coherence for Development 2007 Migration and Developing Countries. Paris: OECD Publications. $\quad$ http://www.oecd-ilibrary.org.gate2.library.lse.ac.uk/policy-coherence-fordevelopment-

2007_514mjz83sfwg.pdf?contentType=/ns/Book\&itemId=/content/book/9789264026100en\&containerItemId $=/$ content $/$ book $/ 9789264026100$ -

en\&accessItemIds $=\&$ mimeType $=$ application $/ \mathrm{pdf}$.

2. , Hrsg. 2008. Agriculture: Improving Policy Coherence for Development. Paris: OECD Publishing. http://www.oecd.org/dataoecd/40/33/40556614.pdf.

2009. Building Blocks for Policy Coherence for Development. Paris: OECD Publishing. http://www.oecd.org/dataoecd/14/53/44704030.pdf.

, Hrsg. 2012. OECD Strategy on Development. Paris: OECD Publishing. http://www.oecd.org/pcd/OECD\%20Development\%20Strategy.pdf.

2013a. „Better Policies for Development. In Focus: Policy Coherence for Development and Global Food Security." Paris: Publishing. http://www.oecd.org/pcd/PoliCoh_PDFforWeb_270513.pdf.

2013b. „Policy coherence for inclusive and sustainable development. OECD and Post-2015 Reflections." Element Paper 8. Paris: OECD. http://www.oecd.org/pcd/POST2015\%20PCD.pdf.

2013c. Policy Instruments to Support Green Growth in Agriculture. Paris: Organisation for Economic Cooperation and Development. http://www.oecd-ilibrary.org/content/book/9789264203525-en. 
2014a. „2014 Report on the implementation of the OECD Strategy on Development“. CMIN(2014)14-ENG. Paris: OECD. https://www.oecd.org/mcm/C-MIN(2014)14-ENG.pdf.

, Hrsg. 2014b. Better Policies for Development 2014. Policy Coherence and Illicit Financial Flows. Paris: OECD Publishing. http://www.oecd-ilibrary.org/development/better-policies-fordevelopment_9789264210325-en.

2015. Better Policies for Development 2015 Policy Coherence and Green Growth: Policy Coherence and Green Growth. Paris: OECD Publishing.

. 2016. „The Framework for Policy Coherence for Sustainable Development“. General Secretariat SG/PCD(2016)1. Paris: OECD.

OECD, and Worldbank, Hrsg. 2006. Integrating Human Rights into Development. 2. Aufl. Paris: OECD Publishing. http://www.oecd-ilibrary.org.gate2.library.lse.ac.uk/integrating-human-rights-intodevelopment_5lgh2z2qg1bn.pdf?contentType=/ns/Book\&itemId=/content/book/97892640221 $02-$ en\&containerItemId=/content $/$ serial $/ 19901372 \&$ accessItemIds=/content $/$ serial $/ 19901372 \& m i$ me'Type $=$ application $/$ pdf.

OECD/DAC. 1996. Building Policy Coherence Tools and Tensions. Paris: Organisation for Economic Cooperation and Development; OECD Washington Center [distributor]. http://books.google.com/books?id=gPd9AAAAIAAJ.

2001. The DAC Guidelines - Poverty Reduction. Paris: OECD Publishing. http://www.oecd.org/development/povertyreduction/2672735.pdf.

2003. „Policy Coherence: vital for global development“. Policy Brief, Nr. OECD Publishing. http://www.oecd.org/pcd/20202515.pdf.

Omelaniuk, Irena. 2012a. Global Perspectives on Migration and Development: GFMD Puerto Vallarta and Beyond. London; New York: Springer Science \& Business Media.

. 2012b. „Introduction; Making the Connections between Migration and Development“. In Global Perspectives on Migration and Development: GFMD Puerto V allarta and Beyond, 1-26. London; New York: Springer Science \& Business Media.

Ostrom, Elinor, and Michael D. McGinnis. 2014. „Social-ecological system framework: initial changes and continuing challenges" Ecology and Society (19(2): 30).

Persson, Asa. 2004. „Environmental Policy Integration: An Introduction“. Background Paper. Policy Integration for Sustainability. Stockholm: Stockholm Environment Institute. https://www.seiinternational.org/mediamanager/documents/Publications/Policy-institutions/pints_intro.pdf.

Picciotto, R. 2005. „The Evaluation of Policy Coherence for Development“. Evaluation 11 (3):311-30. https://doi.org/10.1177/1356389005058479.

Pogge, Thomas W. 2002. World Poverty and Human Rights: Cosmopolitan Responsibilities and Reforms. 1. Aufl. Polity.

Rijksoverheid. 2013. „Result Chains to Assess the Impact of Policy Coherence for Development in Selected Partner Countries“. Amsterdam. http://www.rijksoverheid.nl/documenten-enpublicaties/rapporten/2013/10/22/result-chains-to-assess-the-impact-of-policy-coherence-fordevelopment-in-selected-partner-countries.html.

Rogers, Everett M. 2003. Diffusion of Innovations, 5th Edition. Simon and Schuster.

Sandra Kröger. 2008. Soft Governance in Hard Politics: European Coordination of Anti-Poverty Policies in France and Germany. 1. Aufl. Wiesbaden: VS, Verlfür Sozialwiss.

Siitonen, Lauri. 2015. „Theorising Politics Behind Policy Coherence for Development (PCD)“. The European Journal of Development Research 28 (1):1-12. https://doi.org/10.1057/ejdr.2015.76.

Simmons, Beth, and Zachary Elkins. 2004. „The Globalization of Liberalization: Policy Diffusion in the International Political Economy“ American Political Science Review (98(1)):171-89.

Sinclair, Timothy J. 2012. Global Governance. Cambridge, UK; Malden, MA: Polity Press.

Strang, David. 1991. „Adding Social Structure to Diffusion Models An Event History Framework“. Sociological Methods \& Research 19 (3):324-53. https://doi.org/10.1177/0049124191019003003.

Suwa-Eisenmann, Akiko, and Thierry Verdier. 2006. The Coherence of Trade Flows and Trade Policies with Aid and Investment Flows. 254. Paris: OECD Publishing. http://www.oecd-ilibrary.org/the-coherence-oftrade-flows-and-trade-policies-with-aid-and-investment-

flows_514w6h50d80w.pdf?contentType=/ns/WorkingPaper\&itemId=/content/workingpaper $/ 34$ 
8655721501\&containerItemId $=/$ content $/$ workingpaperseries $/ 18151949 \&$ accessItemIds $=\& m i m e$ Type $=$ application $/$ pdf.

2007. „Aid and Trade“. Oxford Review of Economic Policy 23 (3):481-507. https://doi.org/10.1093/oxrep/grm028.

Thede, Nancy. 2013. „Policy Coherence for Development and Securisation: competing paradigms or stabilising North-South hierarchies?“, Routledge, Third World Quaterly (Vol. 34, No. 5):784-99.

Underdahl, Arild. 1980. „Integrated marine policy. What? Why? How?“, IPC Business Press, , 159-69.

Weiss, Thomas G. 2013. Global Governance What? Why? Whither? Polity Pr.

Whaites, Alan. 2015. „Competing for the Future. Propositions of power and governance in development.“ Background paper, $2015 . \quad$ https://www.oecd.org/dac/governancepeace/publications/documentuploads/Competing $\% 20$ for $\% 20$ the $\% 20$ Future $\% 20$ $\% 20$ Alan $\% 20$ Whaites.pdf.

Wunderlich, Daniel. 2013. „Towards Coherence of EU External Migration Policy? Implementing a Complex Policy“. International Migration 51 (6):26-40. https://doi.org/10.1111/imig.12088.

Young, Alasdair R., and John Peterson. 2013. „We care about you, but ...': the politics of EU trade policy and development". Cambridge Review of International Affairs 26 (3):497-518. https://doi.org/10.1080/09557571.2012.734782. 